\title{
Impact of Cytokine Gene Polymorphism on the HIV-1 Disease Progression and Response to Therapy
}

\section{Sukhvinder Singh and Sunil K Arora*}

Department of Immunopathology, Postgraduate Institute of Medical Education and Research (PGIMER), Chandigarh, India

\begin{abstract}
Inter-individual variations in HIV infection outcome indicate a role of host genetic variations in the HIV disease progression and response to therapy. Cytokines are early key players in HIV infection, which influence the infection outcome by regulating viral replication, persistence and eradication of its reservoirs as well as host immune response. Genetic variations in cytokine genes can alter protein expression resulting in differential infection outcome. In this review we have summarized the available literature on cytokine and receptor variations in HIV infection outcome and response to therapy. A better understanding of cytokine genetic variation in HIV disease progression and response to therapy will help clinicians in better management of HIV infected individuals.
\end{abstract}

Keywords: Cytokines; Single nucleotide polymorphism; HIV disease progression; Response to therapy

\section{Introduction}

Antiretroviral therapy (ART) has lessened the morbidity and mortality among human immunodeficiency virus (HIV) infected individuals, but failed to eradicate the virus completely from the host due to various factors, the most important being the existence of hidden virus reservoirs in the host. So, it continues to be a major global public health problem, with more than 25 million deaths over the past three decades and approximately 34 million people living with HIV infection (http://www.who.int/mediacentre/factsheets/fs360/en/index. $\mathrm{html})$. These statistics have resulted in a continuing intensive research in this arena. The major goal is to elucidate virus and host interactions, identify genes involved in HIV resistance, and restore functionally active lymphocytes in order to facilitate remission [1].

There is considerable heterogeneity among individuals with respect to susceptibility to infection, the rate of depletion of CD4+ T-lymphocytes, which is a hallmark of disease progression and development of acquired immunodeficiency syndrome (AIDS) in the infected host. In typical disease progressors average time for the development of AIDS is 6 to less than 8 years, however, a small subset of HIV-1 infected individuals remain both clinically and immunologically healthy for 10 years or more after sero-conversion termed as long term non progressors (LTNPs) [2]. Conversely, another significant fraction of patients $(10-15 \%)$ are rapid progressors who have a fast CD4+Tcell decline and occurrence of AIDS-related events within the first few years after infection. There are also individuals, who have had repetitive sexual exposure to HIV-1 in extremely high risk situations, but remain uninfected with HIV-1, known as exposed seronegatives (ESNs) [3]. Besides many other factors playing role in this phenomenon, the host genetic makeup seems to be the most important one. From the past more than three decades, intensive research among these unique HIV cohorts has resulted in the identification of several host genetic variants, especially chemokine co-receptors and their natural ligands, immune response genes (IRG), major histocompatibility complex (MHC), and cytokines genes [4]. Among these hosts genetic variations, a deletion of 32 base-pairs (bp) in the CCR5 gene remains the most well accepted finding, known to confer resistance to HIV-1 infection in homozygous individuals and by virtue of which it has successfully entered into the recent gene therapy clinical trials among HIV infected individuals [5].

Cytokines play a central role in regulating the innate and adaptive immune response, hence also have an impact on the pathogenesis of infectious diseases including the HIV infection [6]. Biosynthesis of cytokine levels are well regulated, but inter-individual genetic variations can influence the transcriptional regulation, especially single nucleotide polymorphisms (SNPs) in the promoter and in the exonic region may affect the expression levels of cytokines. This can lead to an altered HIV infection outcome mainly by affecting the establishment, persistence and eradication of HIV (Figure 1). Previously, several studies have reviewed systematically host genetic variations within MHC, chemokines and their natural ligand genes [7-11], but there is a dearth of such reviews on the cytokine and their receptor gene variations in HIV disease progression and response to therapy. Several inconsistencies regarding the association of cytokine gene polymorphism in HIV infection do exist, but here we have exclusively reviewed the role of variations in the cytokine and receptor genes. Besides, in recent years, new cytokines have been shown to influence the HIV pathogenesis, these cytokine genes are also polymorphic and the role of genetic variations in these new players would help in the better understanding of the differential HIV disease progression and/or response to therapy.

\section{Cytokines in HIV Pathogenesis}

Cytokines are involved early in the pathogenesis of HIV infection and during HIV disease progression; their levels are altered depending on the stage of the disease. Several hypotheses have been proposed to explain the decline of $\mathrm{CD} 4+\mathrm{T}$ cell count, but nowadays systemic chronic immune activation is considered as the major driving force, which leads to the development of AIDS [12]. A critical balance of proinflammatory and anti-inflammatory cytokine plays a major role in systemic immune activation and hence HIV disease progression. So, they have a potential to be used as therapeutic option in HIV infection, in fact some cytokines like IL-2, IL-7 are now being evaluated in clinical

*Corresponding author: Sunil K Arora, Department of Immunopathology, Postgraduate Institute of Medical Education and Research (PGIMER), Chandigarh-160012, India, Tel: 911722755192; E-mail: arora.sunil@pgimer.edu.in

Received August 11, 2015; Accepted October 09, 2015; Published October 15, 2015

Citation: Singh S, Arora SK (2015) Impact of Cytokine Gene Polymorphism on the HIV-1 Disease Progression and Response to Therapy. J AIDS Clin Res 6: 506 doi:10.4172/2155-6113.1000506

Copyright: (C) 2015 Singh S, et al. This is an open-access article distributed under the terms of the Creative Commons Attribution License, which permits unrestricted use, distribution, and reproduction in any medium, provided the original author and source are credited. 
Citation: Singh S, Arora SK (2015) Impact of Cytokine Gene Polymorphism on the HIV-1 Disease Progression and Response to Therapy. J AIDS Clin Res 6: 506. doi:10.4172/2155-6113.1000506

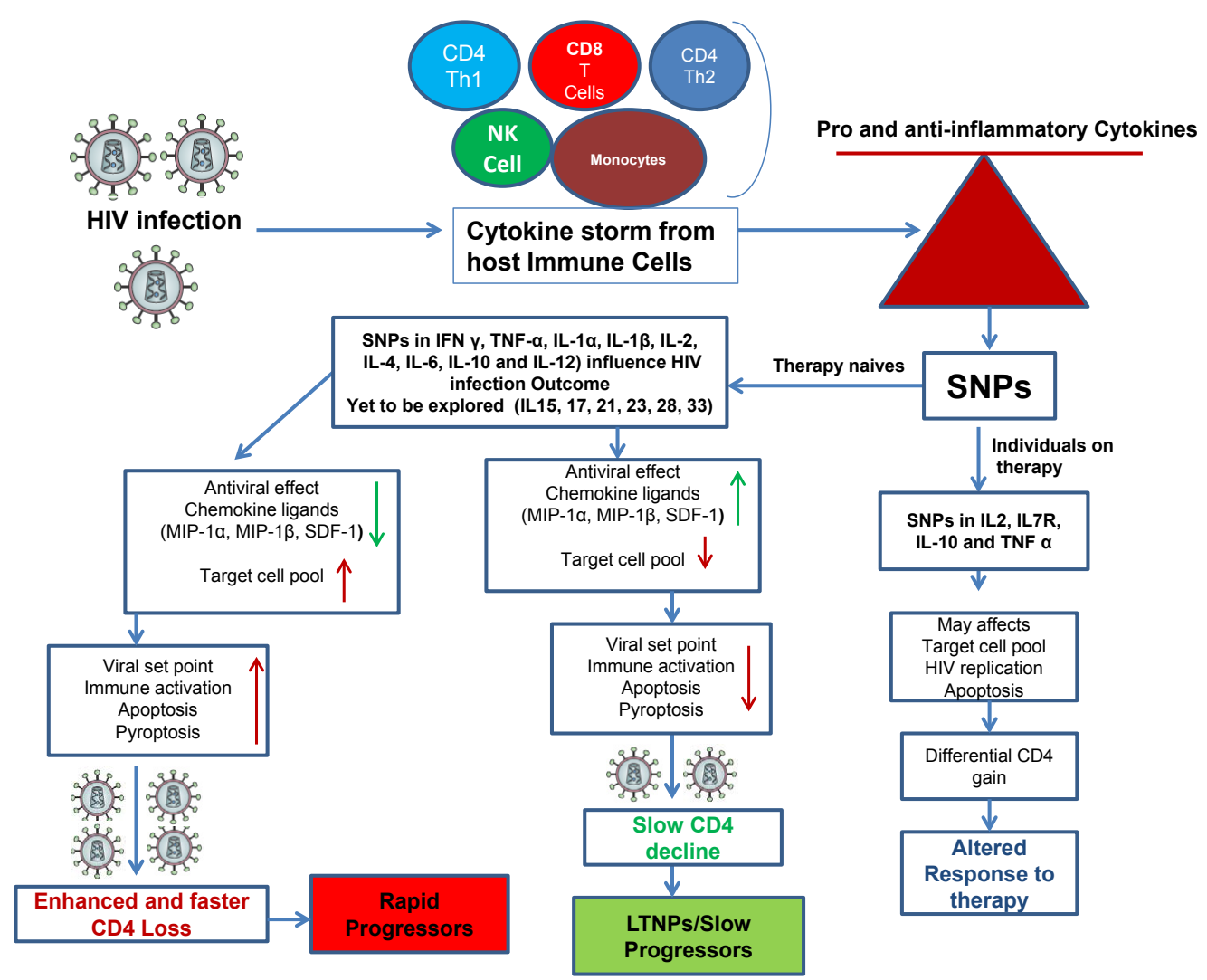

Figure 1: Cytokines play a major role in HIV infection outcome by regulating HIV pathogenesis and host immune response. Immediately following HIV infection there is cytokine storm, which influence the HIV disease pathogenesis and infection outcome. Inter-individual genetic variations in cytokine genes may affect their expression levels. This can lead to an altered balance of pro-inflammatory and anti-inflammatory cytokine milieu, leading to differential HIV disease progression and response to therapy.

trials [13] and anti TNF- $\alpha$ therapy is proposed for HIV therapy as well [14]. Monitoring their levels during HIV disease progression could be crucial for the management of disease. Previous research has provided a compelling link between variations in the cytokine genes that have very subtle, but significant consequences on protein expression and hence altered CD4 count loss, thereby affecting HIV disease progression as well as response to therapy. The major cytokine genetic variations that can affect the HIV disease progression and response to therapy were retrieved for systematic review as discussed in detail below.

\section{Methodology}

We conducted a comprehensive literature search for the research articles reporting the role of cytokine gene polymorphism on the HIV1 disease progression and response to therapy using the most common electronic databases (PubMed and MedLine) (Table 1). The search for research articles was limited to English. We widened our search by using the different key words for polymorphism (SNPs or genetic variation), therapy (ART or HAART) and retrieved 154 articles published on

\begin{tabular}{|c|c|c|c|}
\hline Cytokine Gene & Genetic variation position & Impact on HIV disease progression and response to therapy & References \\
\hline$I F N-\gamma$ & $\begin{array}{l}+874 \mathrm{~T} / \mathrm{A} \\
-179 \mathrm{G} / \mathrm{T}\end{array}$ & $\begin{array}{l}\text { A allele associated with fast disease progression } \\
\text { T allele associated with fast disease progression }\end{array}$ & $\begin{array}{c}{[10,21]} \\
{[23]}\end{array}$ \\
\hline$T N F-\alpha$ & $\begin{array}{l}-238 G / A \\
-308 G / A\end{array}$ & $\begin{array}{l}\text { GA genotype associated with slow disease progression } \\
\text { Inconclusive reports for HIV disease progression }\end{array}$ & $\begin{array}{c}{[36]} \\
{[37,39,40]}\end{array}$ \\
\hline$I L-1 \alpha$ & $\begin{array}{l}-889 \mathrm{C} / \mathrm{T} \\
+4845 \mathrm{G} / \mathrm{T}\end{array}$ & T allele controls HIV replication in patients undergoing therapy & [45] \\
\hline$I L-1 \beta$ & $+3954 \mathrm{C} / \mathrm{T}$ & T allele risk factor for HIV infection & [56] \\
\hline$I L-2$ & $\begin{array}{l}-330 \mathrm{G} / \mathrm{T} \\
+160 \mathrm{~T} / \mathrm{G}\end{array}$ & No association with disease progression & [64] \\
\hline $\begin{array}{l}I L-4 \\
I L-4 R \alpha\end{array}$ & $\begin{array}{l}-589 \mathrm{C} / \mathrm{T} \\
150 \mathrm{~V}\end{array}$ & $\begin{array}{l}\text { Inconclusive reports for T allele with disease progression } \\
\text { I50 a risk factor for HIV infection }\end{array}$ & $\begin{array}{l}{[70-76]} \\
{[77]}\end{array}$ \\
\hline IL-6 & $-174 \mathrm{G} / \mathrm{C}$ & Inconclusive reports for disease progression & {$[64,82]$} \\
\hline$I L-7 R$ & $\begin{array}{l}+2087 \mathrm{~T} / \mathrm{C} \\
+3101 \mathrm{~A} / \mathrm{G}\end{array}$ & $\begin{array}{l}\text { Inconclusive reports for response to therapy } \\
\mathrm{G} \text { allele associated with faster CD4 T cell recovery }\end{array}$ & $\begin{array}{l}{[86,87,88]} \\
{[87]}\end{array}$ \\
\hline IL-10 & $\begin{array}{l}-1082 \mathrm{~A} / \mathrm{G} \\
-592 \mathrm{C} / \mathrm{A}\end{array}$ & $\begin{array}{l}\text { G allele associated with slow disease progression } \\
\text { Inconclusive reports with disease progression }\end{array}$ & $\begin{array}{c}{[33]} \\
{[82,98-100]}\end{array}$ \\
\hline IL-12 & $-1188 \mathrm{~A} / \mathrm{C}$ & No association with HIV disease progression & {$[21,64]$} \\
\hline
\end{tabular}

Table 1: Cytokine gene polymorphisms which affect the HIV disease progression and response to therapy. 
the cytokine gene polymorphism and HIV disease progression, 17 on the response to therapy. We also screened references of selected publications to identify additional articles on the research topic and a total of 80 publications were selected based upon the inclusion criteria as follows: (a) Case-control design; (b) Sufficient statistical data analysis provided like $\mathrm{p}$ value, odds ratio and confidence intervals. Studies were excluded if no control population was included.

\section{Interferon (IFN)- $\gamma$}

IFN- $\gamma$ is a cytokine secreted mainly by T helper type 1 (Th1) cells and natural killer (NK) cells; it is one of the major antiviral cytokines. IFN- $\gamma$ coordinates the trafficking of specific immune cells to sites of inflammation through up-regulation of adhesion molecules and natural chemokine ligands of CCR5 that are regulated on activation, normal $\mathrm{T}$ cells expressed and secreted (RANTES), macrophage inflammatory protein-1 alpha (MIP-1 $\alpha$ ), and macrophage inflammatory protein-1 beta (MIP-1 $\beta$ ) [15]. It promotes a general antiviral state by inducing the conversion of the constitutive proteasome to immune-proteasome [16], up-regulating expression of the TAP transporter proteins [17] and increasing expression and stability of MHC class I molecules [18]. Previously, depending upon the cell type and stage of HIV disease, both suppressive and inductive effects of IFN- $\gamma$ in virus replication have been reported [19]. Alterations in IFN- $\gamma$ levels have been noted in several infections including HIV, and not surprisingly intensive searches to identify association of IFN- $\gamma$ gene variants with these conditions have been carried out [20]. Like most of the cytokines, IFN- $\gamma$ gene coding region has been found to be invariant; however, some polymorphisms such as $+874 \mathrm{~T} / \mathrm{A}$ in the first intron and $-179 \mathrm{G} / \mathrm{T}$ in the promoter region have been identified and shown to be associated with pathological features of HIV infection in therapy naïve individuals. Some studies have reported associations of the IFN- $\gamma+874 \mathrm{~T} / \mathrm{A}$ polymorphism in HIV-1 infected individuals. It has been suggested that individuals homozygous for AA genotype at +874 positions in $I F N-\gamma$ gene have a significantly higher risk of infection and progression to AIDS [10,21]. We have also observed associations of low IFN- $\gamma$ producing genotype (AA) with faster HIV disease progression and high frequency of TT genotype (high IFN- $\gamma$ ) in ESNs cohort (Personal unpublished data). Another important observation regarding IFN- $\gamma$ (+874T/A) polymorphism is significant difference in the allele frequency among healthy individual worldwide, studies indicate a lower frequency of $\mathrm{T}$ allele (+874T/A) among Asians (including Indian) as compared to Caucasian population [22]. The second polymorphism of IFN- $\gamma$ in promoter region $(-179 \mathrm{G} / \mathrm{T})$ has been investigated in African American HIV-1 seroconverters, the TT genotype at this locus was shown to be associated with accelerated progression to $\mathrm{CD} 4<200$ cells $/ \mu \mathrm{L}$, a finding which suggested that this polymorphism in $I F N-\gamma$ is a risk factor for AIDS progression [23]. However, this SNP is most probably absent in Indian population as reported by us and no other published report is available as yet.

\section{Tumor necrosis factor-alpha (TNF-a)}

TNF- $\alpha$ is a pro-inflammatory cytokine, produced by a variety of cells, especially activated macrophages [24] TNF- $\alpha$ is important for a number of $\mathrm{T}$ cell dependent immune processes, including polarization to a Th1 type response, induction of apoptosis, and regulation of proliferation $[25,26]$. The TNF- $\alpha$ gene is mapped on the chromosome 6 in the class III region of the major histocompatibility complex [27]. TNF- $\alpha$ is known to trigger activation of transcription factor nuclear factor (NF)-kB, which can bind to the HIV long terminal repeats (LTR) and promote viral transcription $[28,29]$. TNF- $\alpha$ gene is highly polymorphic, several SNPs in the promoter $(-238 \mathrm{G} / \mathrm{A},-308 \mathrm{G} / \mathrm{A},-857 \mathrm{C} /$
$\mathrm{T},-863 \mathrm{C} / \mathrm{A}$ and $-1031 \mathrm{~T} / \mathrm{C}$ ) region have been described [30], resulting in the altered expression levels [31]. Among these SNPs, variations at -238 and -308 position, which result in G to A substitution are most widely studied and associated with HIV and many other viral infections [32-34]. The presence of - 308 SNP has been related to an increase in TNF- $\alpha$ gene transcription [35]. The presence of $-308 \mathrm{~A}$ allele has been associated with HIV disease progression. In Caucasian population, GA genotype at -238 position in TNF- $\alpha$ gene, has been observed to be associated with very slow disease progression in LTNPs in [36]. More recently, we reported the association of high TNF- $\alpha$ producing haplotype (CAG) with faster HIV disease progression, due to high rate of cell death in carriers of this ha plotype [37]. Previously, in Spaniard cohort, individual polymorphisms at -238G/A, -308G/A and -863C/A loci were not found to be associated with vulnerability to HIV infection, however the haplotype analysis revealed that haplotype GAC was more frequently represented in the exposed uninfected, suggesting that certain haplotypes within $T N F-\alpha$ gene may positively modulate the risk of HIV infection [38]. A recent study from Indian population showed association of GA genotype (-308) with perinatal transmission [39]. However, still many controversies exist regarding the protein expression level of TNF- $\alpha$ and polymorphisms at -238 and -308 positions. Some studies suggest $A$ allele at these positions to be a low producer of TNF- $a$ and these SNPs being in LD with HLA-B ${ }^{\star} 5701$, the carriers have an HLA mediated 'protective' effect during HIV-1 infection [40]. Further extended haplotype and expression analysis is needed to establish the role of genetic variations in the TNF- $\alpha$ gene.

\section{Interleukin-1 $\alpha(\mathrm{IL}-1 \alpha)$}

IL- $1 \alpha$ is a pro-inflammatory cytokine, mainly released by macrophages neutrophils, epithelial cells, and endothelial cells [41]. It is regarded as the primary mediator for systemic inflammatory response. $I L-1 \alpha$ gene is mapped within the $I L-1$ gene cluster on chromosome 2 q1321. Two SNPs in the $I L-1 a$ gene at position $-889 \mathrm{C} / \mathrm{T}$ in the promoter region and $+4845 \mathrm{G} / \mathrm{T}$ have been shown to influence the expression levels, with T allele being a high producer [42-44]. In the context of HIV infection, studies have shown that $\mathrm{T}$ allele at -889 or +4845 position in IL-1a gene may predict the control of HIV replication in individuals undergoing therapy [45]. Besides, a tandem-repeat polymorphism of the $I L-1 R A$ gene (antagonist of $I L-1 \alpha$ ) is also associated with control of HIV-1 viremia in naive as well as antiretroviral treated patients [46].

\section{Interleukin-1 $\beta$ (IL-1 $\beta)$}

$\mathrm{IL}-1 \beta$ is also a pro-inflammatory cytokine, mapped on chromosome 2 and is part of a gene cluster comprising $I L-1 \alpha, I L-1 \beta$, and $I L-1 R N$ $[47,48]$. IL- $1 \beta$ is mainly produced by activated macrophages as a $31-\mathrm{kd}$ pro-protein, it is converted into its active form by proteolytic cleavage of caspase $1[49,50]$. Several polymorphisms have been identified in the $I L-1 \beta$ gene, among these 2 in the promoter $(-511 \mathrm{C} / \mathrm{T}$ and $-31 \mathrm{~T} / \mathrm{C})$ and 1 in exon $5(+3954 \mathrm{C} / \mathrm{T})$ are extensively studied. The $\mathrm{T}$ allele of the exon 5 polymorphism has previously been reported to be associated with an increased protein secretion phenotype [51]. In the context of HIV infection, the balance between IL- $1 \alpha / \beta$ and IL-1R $\alpha$ has been reported to modulate HIV- 1 expression in monocytes [52,53]. While IL- $1 \alpha / \beta$ has been shown to enhance HIV-1 replication, the IL-1Ra, agonist of these, can reduce HIV-1 replication levels in monocytes [54,55]. The role of IL- $1 \beta$ polymorphism at $+3954 \mathrm{C} / \mathrm{T}$ position has earlier been reported in HIV infected therapy naïve individuals [56]. Recent studies have suggested pyroptosis to be a major mechanism of bystander CD4 $\mathrm{T}$ cell depletion, which is an inflammatory cascade primarily initiated through the innate immune sensing of HIV-1 DNA and IL- $1 \beta$ is known to play a key role in initiation of this phenomenon [57]. 


\section{Interleukin-2 (IL-2)}

The IL-2 gene is mapped on chromosome 4. Mainly produced by CD4 and CD8 T cells, IL-2 plays crucial role in regulating both immune activation and homeostasis [58,59]. IL-2 mainly regulates CD4+ T cell production and their survival. In HIV-infected individuals, deficiency of IL-2 production is one of the first immunological defects reported [60]. IL-2 production is related to CD4+ T cell counts and clinical status of the infected individuals, hence, it plays a critical role in HIV disease progression [61]. Besides, it is known to inhibit apoptosis induced by cross-linking of gp120 and CD4 receptor on CD4+ T cells [62]. IL-2 has been used in clinical trials for the treatment of HIV infection. However, it was found to be ineffective in preventing progression to an AIDS in two large clinical trials [63]. Genetic variations in $I L-2$ gene at positions $(-330 \mathrm{G} / \mathrm{T}$ and $+160 \mathrm{~T} / \mathrm{G})$ in North Americans have been studied in therapy naïve individuals with no significant association with HIV infection outcome [64].

\section{Interleukin-4 (IL-4)}

IL-4 is a pleiotropic cytokine produced primarily by activated $\mathrm{CD} 4^{+}+\mathrm{T}$ lymphocytes, mast cells, and basophils $[65,66]$. It regulates the humoral immunity by the differentiation of precursor $\mathrm{T}$ helper cells into the Th2 subset [67]. IL-4 plays a crucial role in shaping the nature of immune response, including the induction and expression of DC-SIGN in-vitro differentiated dendritic cells [68]. In context to HIV-1 infection, IL-4 is reported to differentially regulate two major HIV-1 co-receptors, CXCR4 for syncytium inducing (SI) variants and CCR5 for non-syncytium inducing (NSI) viruses. IL-4 down-regulates CCR5 expression and thus inhibits replication of HIV-1 NSI isolates in human T cells and macrophages. On the other hand, IL- 4 up-regulates the expression of CXCR4 leading to induction of SI variants, mainly observed in advanced stage of HIV disease progression [69]. In addition, the combination of these effects of IL- 4 on HIV-1 replication may be involved in the phenotypic switch from NSI to SI as well as disease progression in HIV-1 infection. Thus, IL-4 plays an important role in viral evolution and HIV disease progression. In $I L-4$ gene two SNPs at $-589 \mathrm{C} / \mathrm{T}$ and -33 positions and one in IL-4 receptor (IL-4R $\alpha$ I50V) have been associated with differential outcome in therapy naïve individuals. Two previous studies based on two independent cohorts (Japanese and French) showed a protective effect of $I L-4-589 \mathrm{~T}$, by reducing viral load in early infection and subsequently delayed HIV disease progression $[70,71]$. In contrary to this, one study of homosexual men showed a delayed acquisition of $\mathrm{X} 4$ virus in carriers of $\mathrm{T}$ allele and no association with HIV disease progression [72]. Subsequent studies showed either no association of the $I L-4-589 \mathrm{~T}$ SNP with HIV disease progression $[73,74]$, or protective effect of this polymorphism was observed $[64,75,76]$. One study from the Indian population showed no association between the $I L-4-589 \mathrm{~T}$ allele and HIV-1 susceptibility/progression, however $I L-4 R \alpha$ I50V was found to be a risk factor for HIV-1 infection [77]. It is possible that different results of IL- 4 promoter polymorphism and HIV-1 susceptibility/progression might be due to multi gene interactions and linkage disequilibrium of $I L-4$ SNPs leading to cis and trans effect, that might affect disease progression in HIV-1-infected individuals and has variable effects depending upon race/ethnicity.

\section{Interleukin- 6 (IL-6)}

IL-6, a multifunctional cytokine that has been implicated in a variety of cellular functions including cell proliferation and differentiation, hematopoiesis and induction of acute phase reaction, inhibits apoptosis, and leads to an increase in vascular endothelial growth factor [78]. It is localized on chromosome 7p21-24 with an upstream promoter containing $303 \mathrm{bp}[79,80]$. IL-6 gene is polymorphic within its promoter region ( $\mathrm{G}$ to $\mathrm{C}$ transversion at position -174) is associated with reduced IL- 6 production [81]. For IL-6, strong association was observed between IL6 -174G/C and susceptibility to AIDS related malignancies like Kaposi sarcoma in HIV-infected men. Among other two studies, one showed a lower frequency of low producing genotype CC in HIV infected therapy naïve cohort [64], while another showed the combination of low IL- 6 producing genotype (CC) and high IL-10 producing genotype (CC at $592 \mathrm{C} / \mathrm{A}$ ) to be non-significantly associated with rapid disease progression [82]. Although, IL-6 is an important cytokine, but there is a lack of information on IL- 6 polymorphism in HIV infected individuals, further studies on unique HIV cohorts are needed to establish its role in HIV disease progression.

\section{Interleukin-7 (IL-7) and Interleukin-7 receptor (IL-7R)}

IL-7 is a hematopoietic growth factor secreted mainly by stromal cells in the bone marrow and thymus. IL-7 is a $25-\mathrm{kD}$ glycoprotein, essential for T-cell development, survival, and proliferation [83]. It exerts its biological effects through the IL-7R complex, IL-7 receptor $\alpha$ chain (CD127), which binds IL-7, and thymic stromal lymphopoietin and the IL-2 receptor $\gamma$ chain (CD132). It has been found to be a cofactor for $\mathrm{V}(\mathrm{D}) \mathrm{J}$ rearrangement of T-cell receptor beta during early T-cell development [84]. More recently IL-7 has entered the clinical arena and has been shown that it is capable of inducing increase in the numbers of CD4+ and CD8+ T cells, although it can lead to increase in latent HIV replication also [85]. Receptor of IL-7 gene, mainly the a chain is polymorphic with the existence of four non-synonymous SNPs in the exons; rs $1494558(+510 \mathrm{C} / \mathrm{T}$ in exon 2$), \mathrm{rs} 1494555(+1237 \mathrm{~A} / \mathrm{G}$ in exon 4), rs6897932 (+2087T/C in exon 6) and rs3194051 (+3101A/G in exon 8), all of these give rise to amino acid substitutions that impact the expression of IL7RA and/or clinical outcome of HIV infection. In fact it is the major cytokine receptor which influences the response to therapy in patients undergoing therapy. Previously, an association between IL-7R rs6897932 polymorphism and faster CD4 count recovery in individuals undergoing therapy has been reported in Caucasians, however in contrast, in African population same polymorphism (rs6897932) is shown to be associated with slow recovery while another polymorphism, rs3194051 was associated with faster CD4 T-cell recovery [86,87]. In Danish cohort undergoing therapy, polymorphisms in the IL-7R at (rs6897932; T-allele) was found to be a significant predictor of faster immune recovery after initiation of therapy [88], while in Zimbabwe cohort same polymorphism (rs6897932) T-allele homozygosity was found to be associated with a lower rate of decline in the CD4 cell count in untreated HIV infected individuals [89]. Thus, polymorphisms in or adjacent to the $I L-7 R$ gene may result in an altered expression of IL-7R on T cells and/or a dysfunctional interaction between IL-7 and IL-7R that may affect the CD4 cell count and progression to AIDS and death [90]. However, further extended analysis of $I L-7 R$ gene along with functional analysis may be helpful to clear these inconsistencies. Also, there is a lack of $I L-7 R$ gene polymorphism studies from Asian population; this could have implication in clinical management of HIV infected individuals undergoing therapy.

\section{Interleukin-10 (IL-10)}

IL-10 is a pleiotropic cytokine produced mainly by monocytes, macrophages, Th- 2 cells and B-lymphocytes. It can both stimulate as well as suppress the immune response [91]. IL-10 has been shown to inhibit various immune reactions, such as antigen presentation, cytokine production, macrophage activation, and antigen specific $\mathrm{T}$ cell proliferation [92]. It can also suppress IFN- $\gamma$, TNF- $\alpha$, granulocytemacrophage colony-stimulating factor (GM-CSF), and lymphotoxin 
production [91]. IL-10 has been found to up-regulate the CXCR4 expression and X4 HIV infection of dendritic cells in-vitro, although this did not affect the efficiency of viral transmission to autologous CD4+T cells, an event involving DC-SIGN rather than conventional viral receptors [93]. Depending on the concentration of IL-10, both inhibitory and inductive effects on in-vitro HIV replication have been observed; indicating its action as a double edged sword. IL-10 levels have been found to be elevated, particularly in the lymph nodes of HIV-infected individuals, whereas progression to AIDS has been correlated with an IL-10 promoter variant associated with a decreased IL-10 expression [94]. It has been suggested that IL-10 acts as a general inhibitor of proliferative and cytokine responses of both Th1 and Th2 cells in-vitro as well as in-vivo. The levels of IL-10 production are crucial to immune regulation and controlling the balance between the inflammatory and humoral responses. The capacity for IL-10 production in individuals is correlated with the genetic composition of the IL-10 locus. It has been reported that approximately $75 \%$ of the variation in IL-10 secretion capacity in humans, derive from genetic factors and these genetic differences contribute to disease susceptibility [95]. Several polymorphic sites within the $I L-10$ gene promoter region have been described, including three bi-allelic polymorphisms at position $-1082 \mathrm{~A} / \mathrm{G},-819 \mathrm{C} / \mathrm{T}$, and $-592 \mathrm{C} / \mathrm{A}$ from the transcription start site [96]. It has been proposed that the $-1082 \mathrm{~A} / \mathrm{G}$ polymorphism lies in a putative ETS like transcription factor binding site, while the $-819 \mathrm{C} / \mathrm{T}$ polymorphism may affect an estrogen receptor element. Similarly, $-592 \mathrm{C} / \mathrm{A}$ polymorphism has been shown to be in a region of the negative regulatory function, making them important loci for study in relation to disorders affected by levels [97]. Shin et al. (2000) reported that the individuals carrying the A allele at -592 position in $I L-10$ gene were at increased risk for HIV-1 infection, and once infected, they progressed to AIDS more rapidly, especially in the later stages of HIV1 infection [94]. Subsequent studies however reported inconsistently about the association for the same SNP with HIV disease progression [82,98-100]. At -1082 position of the $I L-10$ gene, in Zimbabwean cohort, carriers of $\mathrm{G}$ allele (enhanced IL-10 production) were reported to have reduced mortality and attenuated CD4 count decline in therapy naïve individuals [33], indicating an important role of $I L-10$ gene polymorphism in HIV disease progression. Interestingly, recently we also observed that a combination of low IL-10 (at -592 position) and low IFN $-\gamma$ (+874 position) producing genotype 'AA' in these two genes was associated with faster disease progression (unpublished personal data). So, there is a need to study the combinatorial effect of variations in multiple interacting genes to better understand the intricate role of cytokine genetic polymorphisms in HIV disease progression as well as in other infectious diseases.

\section{Interleukin-12 (IL-12)}

IL-12 is naturally produced by dendritic cells, macrophages and lymphocytes [101]. It is involved in the differentiation of naive $\mathrm{T}$ cells into Th1 cells and is known as a T cell-stimulating factor, which can stimulate the growth and function of $\mathrm{T}$ cells [102]. It stimulates the production of IFN- $\gamma$ and TNF- $\alpha$ from T cells and NK cells, and reduces IL- 4 mediated suppression of IFN- $\gamma$. In the context of HIV infection, contradictory reports are available which indicate that both immune over-activation and immune-deficiency are reflected in IL-12 production during HIV infection. Although, IL-12 could be useful to enhance deficient cell-mediated immunity, it also has potential proinflammatory and HIV-enhancing effects. Therefore, more studies are needed to unravel the role of dysregulated IL-12 production in HIV pathogenesis. IL-12 is a heterodimer of the polypeptides p35 and p40. $I L-12 \mathrm{~B}$, the gene encoding IL-12 $\mathrm{p} 40$, is polymorphic, and a functional
SNP of the 3'-untranslated region at position -1188 resulting in A to C change. However, in context of HIV no association has been found with HIV disease progression [21, 64].

\section{Limitations of Current Review Article}

Although, we have reviewed literature systematically but sample size in selected research articles is not uniform. Hence, selection of studies with larger sample size is needed to better understand the intricate role of cytokines. Besides, lack of functional studies in the majority of research articles is also the major limitation to reach at conclusions.

\section{Current Interests and Future Prospects}

In the recent years, role of IL-15, IL-17, IL-21, IL-23, IL-28B and IL-33 cytokines has just started to come into the light. Recently, IL21 was reported to induce antiviral microRNA-29 in CD4+ T cells through STAT3, which further limits the HIV-1 infection [103]. Functional SNPs exist in the genes encoding these cytokines, however, in case of HIV infection; there is a need to establish the role of genetic association in these cytokines with disease profile. With the recent revolution in genome editing tools like zinc-finger nucleases (ZFNs), transcription activator-like effector nucleases (TALENs) and type II clustered regularly interspaced short palindromic repeats (CRISPER/ Cas9, has successfully modified autologous CD4 cells by editing CCR 5 gene (introducing $\triangle 32$ mutation) and subsequent infusion of edited CD4+ T cells in patients has shown encouraging results $[5,104]$. So, continuous efforts should be undertaken in diverse human populations infected with a variety of HIV-1 subtypes in order to understand fully the complexity of host genetic variations, knowledge gained from this could be used to completely eradicate the HIV infection. Recent advancements in genomic and transcriptomic arena have widened the scope of functional aspects of variations on cis and trans quantitative trait loci. In fact, it has just started to gain better insight and may be helpful in explaining controversies regarding the expression analysis. Advanced data analysis skills like haplotyping, linkage disequilibrium and multifactor dimension reduction analysis of cytokine variations can provide a better insight into the altered balance of pro-inflammatory and anti-inflammatory cytokines. Finally, the functional analysis of the impact of genetic variations would also be important to fully understand both, the inconsistencies as well as differential HIV disease progression arising out of these genetic alterations.

\section{Acknowledgment}

We gratefully acknowledge Indian Council of Medical Research (ICMR), New Delhi, India for providing senior research fellowship to Sukhvinder Singh.

\section{References}

1. Mehla R, Ayyavoo V (2012) Gene array studies in HIV-1 infection. Curr HIV/ AIDS Rep 9: 34-43.

2. Langford SE, Ananworanich J, Cooper DA (2007) Predictors of disease progression in HIV infection: A review. AIDS Res Ther 4: 11

3. Fowke KR, Nagelkerke NJ, Kimani J, Simonsen JN, Anzala AO, et al. (1996) Resistance to HIV-1 infection among persistently seronegative prostitutes in Nairobi, Kenya. Lancet 348: 1347-1351.

4. Samson M, Libert F, Doranz BJ, Rucker J, Liesnard C, et al. (1996) Resistance to HIV-1 infection in caucasian individuals bearing mutant alleles of the CCR- 5 chemokine receptor gene. Nature 382: 722-725.

5. Tebas P, Stein D, Tang WW, Frank I, Wang SQ, et al. (2014) Gene editing of CCR5 in autologous CD4 T cells of persons infected with HIV. N Engl J Med 370: 901-910.

6. Vandergeeten C, Fromentin R, Chomont N (2012) The role of cytokines in the establishment, persistence and eradication of the HIV reservoir. Cytokine Growth Factor Rev 23: 143-149. 
Citation: Singh S, Arora SK (2015) Impact of Cytokine Gene Polymorphism on the HIV-1 Disease Progression and Response to Therapy. J AIDS Clin Res 6: 506. doi:10.4172/2155-6113.1000506

7. Lama J, Planelles V (2007) Host factors influencing susceptibility to HIV infection and AIDS progression. Retrovirology 4: 52.

8. Hunt PW, Carrington M (2008) Host genetic determinants of HIV pathogenesis: An immunologic perspective. Curr Opin HIV AIDS 3: 342-348.

9. Kaur G, Mehra N (2009) Genetic determinants of HIV-1 infection and progression to AIDS: Immune response genes. Tissue Antigens 74: 373-385.

10. Sharma G, Kaur G, Mehra N (2011) Genetic correlates influencing immunopathogenesis of HIV infection. Indian J Med Res 134: 749-768.

11. McLaren PJ, Carrington M (2015) The impact of host genetic variation on infection with HIV-1. Nat Immunol 16: 577-583.

12. Miedema F, Hazenberg MD, Tesselaar K, van Baarle D, de Boer RJ, et al (2013) Immune activation and collateral damage in AIDS pathogenesis. Front Immunol 4: 298.

13. Sereti I, Dunham RM, Spritzler J, Aga E, Proschan MA, et al. (2009) IL-7 administration drives T cell-cycle entry and expansion in HIV-1 infection. Blood 113: 6304-6314.

14. Kumar A, Abbas W, Herbein G (2013) TNF and TNF receptor superfamily members in HIV infection: New cellular targets for therapy? Mediators Inflamm 2013: 484378

15. Appay V, Rowland-Jones SL (2001) RANTES: a versatile and controversial chemokine. Trends Immunol 22: 83-87.

16. Groettrup M, Soza A, Eggers M, Kuehn L, Dick TP, et al. (1996) A role for the proteasome regulator PA28alpha in antigen presentation. Nature 381: 166-168.

17. Cramer LA, Nelson SL, Klemsz MJ (2000) Synergistic induction of the Tap-1 gene by IFN-gamma and lipopolysaccharide in macrophages is regulated by STAT1. J Immunol 165: 3190-3197.

18. Wallach D, Fellous M, Revel M (1982) Preferential effect of gamma interferon on the synthesis of HLA antigens and their mRNAs in human cells. Nature 299 833-836

19. Poli G, Kinter AL, Fauci AS (1994) Interleukin 1 induces expression of the human immunodeficiency virus alone and in synergy with interleukin 6 in chronically infected U1 cells: Inhibition of inductive effects by the interleukin 1 receptor antagonist. Proc Natl Acad Sci U S A 91: 108-112.

20. Bream JH, Ping A, Zhang X, Winkler C, Young HA (2002) A single nucleotide polymorphism in the proximal IFN-gamma promoter alters control of gene transcription. Genes and immunity 3: 165-169.

21. Sobti RC, Salih AM, Nega B, Seyed AH, Rupinder K, et al. (2010) Insights into the role of IL-12B and IFN-gamma cytokine gene polymorphisms in HIV-1/AIDS infection. Folia Biol (Praha) 56: 110-115.

22. Lio D, Marino V, Serauto A, Gioia V, Scola L, et al. (2002) Genotype frequencies of the +874T-->A single nucleotide polymorphism in the first intron of the interferon-gamma gene in a sample of Sicilian patients affected by tuberculosis. Eur J Immunogenet 29: 371-374.

23. An P, Vlahov D, Margolick JB, Phair J, O'Brien TR, et al. (2003) A tumor necrosis factor-alpha-inducible promoter variant of interferon-gamma accelerates CD4+ $\mathrm{T}$ cell depletion in human immunodeficiency virus-1-infected individuals. The Journal of infectious diseases 188: 228-231.

24. Beutler B, Greenwald D, Hulmes JD, Chang M, Pan YC, et al. (1985) Identity of tumor necrosis factor and the macrophage-secreted factor cachectin. Nature 316: 552-554.

25. Beutler B, van Huffel C (1994) Unraveling function in the TNF ligand and receptor families. Science 264: 667-668.

26. Zheng L, Fisher G, Miller RE, Peschon J, Lynch DH, et al. (1995) Induction of apoptosis in mature T cells by tumor necrosis factor. Nature 377: 348-351.

27. Nedwin GE, Naylor SL, Sakaguchi AY, Smith D, Jarrett-Nedwin J, et al. (1985) Human lymphotoxin and tumor necrosis factor genes: structure, homology and chromosomal localization. Nucleic acids research. 13: 6361-6373.

28. Nabel G, Baltimore D (1987) An inducible transcription factor activates expression of human immunodeficiency virus in T cells. Nature 326: 711-713.

29. Duh EJ, Maury WJ, Folks TM, Fauci AS, Rabson AB (1989) Tumor necrosis factor alpha activates human immunodeficiency virus type 1 through induction of nuclear factor binding to the NF-kappa B sites in the long terminal repeat. Proceedings of the National Academy of Sciences of the United States of America. 86: 5974-5978.
30. Thio CL, Goedert JJ, Mosbruger T, Vlahov D, Strathdee SA, et al. (2004) An analysis of tumor necrosis factor alpha gene polymorphisms and haplotypes with natural clearance of hepatitis C virus infection. Genes Immun 5: 294-300.

31. Hajeer AH, Lazarus M, Turner D, Mageed RA, Vencovsky J, et al. (1998) IL-10 gene promoter polymorphisms in rheumatoid arthritis. Scand J Rheumatol 27 142-145.

32. Nolan D, Moore C, Castley A, Sayer D, Mamotte C, et al. (2003) Tumou necrosis factor-alpha gene -238G/A promoter polymorphism associated with a more rapid onset of lipodystrophy. AIDA 17: 121-123.

33. Erikstrup C, Kallestrup P, Zinyama-Gutsire RB, Gomo E, Butterworth AE, et al (2007) Reduced mortality and CD4 cell loss among carriers of the interleukin-10 $-1082 \mathrm{G}$ allele in a Zimbabwean cohort of HIV-1-infected adults. AIDS 21: 2283 2291.

34. Tayebi S, Mohamadkhani A (2012) The TNF-ît -308 Promoter Gene Polymorphism and Chronic HBV Infection. Hepat Res Treat 2012: 493219.

35. Kaijzel EL, van Krugten MV, Brinkman BM, Huizinga TW, van der Straaten T, et al. (1998) Functional analysis of a human tumor necrosis factor alpha (TNFalpha) promoter polymorphism related to joint damage in rheumatoid arthritis. Molecular medicine 4: 724-733.

36. Nasi M, Riva A, Borghi V, D'Amico R, Del Giovane C, et al. (2013) Novel genetic association of TNF-alpha-238 and PDCD1-7209 polymorphisms with long-term non-progressive HIV-1 infection Int J Infect Dis 17: e845-850.

37. Singh S, Sharma A, Arora SK (2014) High producer haplotype (CAG) of -863C/ $A,-308 \mathrm{G} / \mathrm{A}$ and $-238 \mathrm{G} / \mathrm{A}$ polymorphisms in the promoter region of TNF-alpha gene associate with enhanced apoptosis of lymphocytes in HIV-1 subtype C infected individuals from North India. PloS one 9: e98020.

38. Veloso S, Olona M, Garcia F, Domingo P, Alonso-Villaverde C, et al. (2010) Effect of TNF-alpha genetic variants and CCR5 Delta 32 on the vulnerability to HIV-1 infection and disease progression in Caucasian Spaniards. BMC Med Genet 11: 63.

39. Ahir S, Mania-Pramanik J, Chavan V, Kerkar S, Samant-Mavani P, et al. (2015) Genetic variation in the promoter region of pro-inflammatory cytokine TNF-l̂t in perinatal HIV transmission from Mumbai, India. Cytokine 72: 25-30.

40. Simpson PD, Moysi E, Wicks K, Sudan K, Rowland-Jones SL, et al. (2012) Functional differences exist between TNFalpha promoters encoding the common -237G SNP and the rarer HLA-B*5701-linked A variant. PloS one 7 : e40100.

41. Dinarello CA (1997) Interleukin-1. Cytokine Growth Factor Rev 8: 253-265.

42. McDowell TL, Symons JA, Ploski R, Forre O, Duff GW (1995) A genetic association between juvenile rheumatoid arthritis and a novel interleukin-1 alpha polymorphism. Arthritis and rheumatism 38: 221-228.

43. Hulkkonen J, Laippala P, Hurme M (2000) A rare allele combination of the interleukin-1 gene complex is associated with high interleukin-1 beta plasma levels in healthy individuals. Eur Cytokine Netw 11: 251-255.

44. Dominici R, Cattaneo M, Malferrari G, Archi D, Mariani C, et al. (2002) Cloning and functional analysis of the allelic polymorphism in the transcription regulatory region of interleukin-1 alpha. Immunogenetics 54: 82-86.

45. Price P, James I, Fernandez S, French MA (2004) Alleles of the gene encoding IL-1alpha may predict control of plasma viraemia in HIV-1 patients on highly active antiretroviral therapy. AIDS 18: 1495-1501.

46. Witkin SS, Linhares IM, Gerber S, Caetano ME, Segurado AC (2001) Interleukin-1 receptor antagonist gene polymorphism and circulating levels of human immunodeficiency virus type 1 RNA in Brazilian women. J Virol 75: 6242-6244.

47. Webb AC, Collins KL, Auron PE, Eddy RL, Nakai H, et al. (1986) Interleukin-1 gene (IL1) assigned to long arm of human chromosome 2. Lymphokine Res 5: 77-85.

48. Nicklin MJ, Weith A, Duff GW (1994) A physical map of the region encompassing the human interleukin-1 alpha, interleukin-1 beta, and interleukin-1 receptor antagonist genes. Genomics 19: 382-384.

49. Cerretti DP, Kozlosky CJ, Mosley B, Nelson N, Van Ness K, et al. (1992) Molecular cloning of the interleukin- 1 beta converting enzyme. Science 256 97-100.

50. Rubartelli A, Cozzolino F, Talio M, Sitia R (1990) A novel secretory pathway for interleukin-1 beta, a protein lacking a signal sequence. EMBO J 9: 1503-1510. 
Citation: Singh S, Arora SK (2015) Impact of Cytokine Gene Polymorphism on the HIV-1 Disease Progression and Response to Therapy. J AIDS Clin Res 6: 506. doi:10.4172/2155-6113.1000506

51. Pociot F, Mølvig J, Wogensen L, Worsaae H, Nerup J (1992) A Taq polymorphism in the human interleukin-1 beta (IL-1 beta) gene correlates with IL-1 beta secretion in vitro. Eur J Clin Invest 22: 396-402.

52. Goletti D, Kinter AL, Hardy EC, Poli G, Fauci AS (1996) Modulation of endogenous IL-1 beta and IL-1 receptor antagonist results in opposing effects on HIV expression in chronically infected monocytic cells. J immunol 156: 3501-3508.

53. Zavala F, Rimaniol AC, Boussin F, Dormont D, Bach JF, et al. (1995) HIV predominantly induces IL-1 receptor antagonist over IL-1 synthesis in human primary monocytes. J Immunol 155: 2784-2793.

54. Poli G, Biswas P, Fauci AS (1994) Interferons in the pathogenesis and treatment of human immunodeficiency virus infection. Antiviral Res 24: 221-233.

55. Granowitz EV, Saget BM, Wang MZ, Dinarello CA, Skolnik PR (1995) Interleukin 1 induces HIV-1 expression in chronically infected U1 cells: blockade by interleukin 1 receptor antagonist and tumor necrosis factor binding protein type 1. Molecular medicine 1: 667-677.

56. Pontillo A, Oshiro TM, Girardelli M, Kamada AJ, Crovella S, et al. (2012) Polymorphisms in inflammasome' genes and susceptibility to HIV-1 infection. J Acquir Immune Defic Syndr 59: 121-125.

57. Doitsh G, Galloway NL, Geng X, Yang Z, Monroe KM, et al. (2014) Cell death by pyroptosis drives CD4 T-cell depletion in HIV-1 infection. Nature 505: 509514.

58. Smith KA (1988) Interleukin-2: Inception, impact, and implications. Science 240: 1169-1176.

59. Malek TR (2008) The biology of interleukin-2. Annu Rev Immunol 26: 453-479.

60. Kinter A, Fauci AS (1996) Interleukin-2 and human immunodeficiency virus infection: pathogenic mechanisms and potential for immunologic enhancement. Immunologic research 15: 1-15.

61. Meyaard L, Hovenkamp E, Keet IP, Hooibrink B, de Jong IH, et al. (1996) Single cell analysis of IL- 4 and IFN-gamma production by T cells from HIVinfected individuals: decreased IFN-gamma in the presence of preserved IL-4 production. J Immunol 157: 2712-2718.

62. Radrizzani M, Accornero P, Amidei A, Aiello A, Delia D, et al. (1995) IL-12 inhibits apoptosis induced in a human Th1 clone by gp120/CD4 cross-linking and CD3/TCR activation or by IL-2 deprivation. Cell Immunol 161: 14-21.

63. Goujard C, Marcellin F, Hendel-Chavez H, Burgard M, Meiffredy V, et al. (2007) Interruption of antiretroviral therapy initiated during primary HIV-1 infection: impact of a therapeutic vaccination strategy combined with interleukin (IL)-2 compared with IL-2 alone in the ANRS 095 Randomized Study. AIDS research and human retroviruses 23: 1105-1113.

64. Wang C, Song W, Lobashevsky E, Wilson CM, Douglas SD, et al. (2004) Cytokine and chemokine gene polymorphisms among ethnically diverse North Americans with HIV-1 infection. J Acquir Immune Defic Syndr 35: 446-454.

65. Paul WE (1991) Interleukin-4: A prototypic immunoregulatory lymphokine. Blood 77: 1859-1870.

66. Keegan AD, Nelms K, Wang LM, Pierce JH, Paul WE (1994) Interleukin 4 receptor: Signaling mechanisms. Immunol Today 15: 423-432.

67. Romagnani S (1995) Biology of human TH1 and TH2 cells. J Clin Immunol 15 121-129.

68. Relloso M, Puig-Kröger A, Pello OM, Rodríguez-Fernández JL, de la Rosa G, et al. (2002) DC-SIGN (CD209) expression is IL-4 dependent and is negatively regulated by IFN, TGF-beta, and anti-inflammatory agents. J Immunol 168: 2634-2643.

69. Wang J, Roderiquez G, Oravecz T, Norcross MA (1998) Cytokine regulation of human immunodeficiency virus type 1 entry and replication in human monocytes/macrophages through modulation of CCR5 expression. Journal of virology 72: 7642-7647

70. Nakayama EE, Hoshino Y, Xin X, Liu H, Goto M, et al. (2000) Polymorphism in the interleukin-4 promoter affects acquisition of human immunodeficiency virus type 1 syncytium-inducing phenotype. J Virol 74: 5452-5459.

71. Nakayama EE, Meyer L, Iwamoto A, Persoz A, Nagai Y, et al. (2002) Protective effect of interleukin-4 -589T polymorphism on human immunodeficiency virus type 1 disease progression: Relationship with virus load. The Journal of infectious diseases 185: 1183-1186.
72. Kwa $D$, van Rij RP, Boeser-Nunnink B, Vingerhoed J, Schuitemaker $H$ (2003) Association between an interleukin-4 promoter polymorphism and the acquisition of CXCR4 using HIV-1 variants. AIDS 17: 981-985.

73. Modi WS, O'Brien TR, Vlahov D, Buchbinder S, Gomperts E, et al. (2003) Haplotype diversity in the interleukin-4 gene is not associated with HIV-1 transmission and AIDS progression. Immunogenetics 55: 157-164.

74. Singh KK, Hughes MD, Chen J, Spector SA (2004) Lack of protective effects of interleukin-4 -589-C/T polymorphism against HIV-1-related disease progression and central nervous system impairment, in children. The Journal of infectious diseases 189: 587-592.

75. Vasilescu A, Heath SC, Ivanova R, Hendel H, Do H, et al. (2003) Genomic analysis of Th1-Th2 cytokine genes in an AIDS cohort: Identification of IL4 and IL10 haplotypes associated with the disease progression. Genes and immunity 4: 441-449.

76. Wichukchinda N, Nakayama EE, Rojanawiwat A, Pathipvanich P, Auwanit W, et al. (2006) Protective effects of IL4-589T and RANTES-28G on HIV-1 disease progression in infected Thai females. AIDS 20: 189-196.

77. Chatterjee A, Rathore A, Dhole TN (2009) Association of IL-4 589 C/T promote and IL-4Ralphal50V receptor polymorphism with susceptibility to HIV-1 infection in North Indians. J Med Virol 81: 959-965.

78. May LT, Santhanam U, Sehgal PB (1991) On the multimeric nature of natura human interleukin-6. J Biol Chem 266: 9950-9955.

79. Akira S, Taga T, Kishimoto T (1993) Interleukin-6 in biology and medicine. Adv Immunol 54: 1-78.

80. Bowcock AM, Kidd JR, Lathrop GM, Daneshvar L, May LT, et al. (1988) The human "interferon-beta 2/hepatocyte stimulating factor/interleukin-6" gene: DNA polymorphism studies and localization to chromosome $7 \mathrm{p} 21$. Genomics 3: 8-16.

81. Fishman D, Faulds G, Jeffery R, Mohamed-Ali V, Yudkin JS, et al. (1998) The effect of novel polymorphisms in the interleukin-6 (IL-6) gene on IL-6 transcription and plasma IL-6 levels, and an association with systemic-onset juvenile chronic arthritis. J Clin Invest 102: 1369-1376.

82. Sobti RC, Berhane N, Mahedi SA, Kler R, Hosseini SA, et al. (2010) Polymorphisms of IL-6 174 G/C, IL-10 -592 C/A and risk of HIVIAIDS among North Indian population. Mol Cell Biochem 337: 145-152.

83. Schluns KS, Kieper WC, Jameson SC, Lefrançois L (2000) Interleukin-7 mediates the homeostasis of naïve and memory CD8 $T$ cells in vivo. Nat Immunol 1: 426-432.

84. Muegge K, Vila MP, Durum SK (1993) Interleukin-7: A cofactor for V(D)J rearrangement of the $T$ cell receptor beta gene. Science 261: 93-95.

85. Levy Y, Lacabaratz C, Weiss L, Viard JP, Goujard C, et al. (2009) Enhanced T cell recovery in HIV-1-infected adults through IL-7 treatment. J Clin Invest 119: 997-1007.

86. Rajasuriar R, Booth DR, Gouillou M, Spelman T, James I, et al. (2012) The role of SNPs in the alpha-chain of the IL-7R gene in CD4+ T-cell recovery in HIV-infected African patients receiving suppressive cART. Genes and immunity 13: 83-93.

87. Rajasuriar R, Gouillou M, Spelman T, Read T, Hoy J, et al. (2011) Clinical predictors of immune reconstitution following combination antiretroviral therapy in patients from the Australian HIV Observational Database. PloS one 6 : e20713.

88. Hartling HJ, Thorner LW, Erikstrup C, Harritshoj LH, Kronborg G, et al. (2014) Polymorphism in interleukin-7 receptor alpha gene is associated with faster CD4(+) T-cell recovery after initiation of combination antiretroviral therapy AIDS 28: 1739-1748.

89. Hartling HJ, Thørner LW, Erikstrup C, Zinyama R, Kallestrup P, et al. (2013) Polymorphisms in the interleukin-7 receptor $\hat{I} \pm$ gene and mortality in untreated HIV-infected individuals. AIDS 27: 1615-1620.

90. Limou S, Melica G, Coulonges C, Lelièvre JD, Do H, et al. (2012) Identification of IL7RA risk alleles for rapid progression during HIV-1 infection: A comprehensive study in the GRIV cohort. Curr HIV Res 10: 143-150.

91. Moore KW, de Waal Malefyt R, Coffman RL, O'Garra A (2001) Interleukin-10 and the interleukin-10 receptor. Annu Rev Immunol 19: 683-765.

92. Mocellin S, Marincola FM, Young HA (2005) Interleukin-10 and the immune response against cancer: A counterpoint. J Leukoc Biol 78: 1043-1051. 
Citation: Singh S, Arora SK (2015) Impact of Cytokine Gene Polymorphism on the HIV-1 Disease Progression and Response to Therapy. J AIDS Clin Res 6: 506. doi:10.4172/2155-6113.1000506

93. Ancuta P, Bakri Y, Chomont N, Hocini H, Gabuzda D, et al. (2001) Opposite effects of IL-10 on the ability of dendritic cells and macrophages to replicate primary CXCR4-dependent HIV-1 strains. J Immunol 166: 4244-4253.

94. Shin HD, Winkler C, Stephens JC, Bream J, Young H, et al. (2000) Genetic restriction of HIV-1 pathogenesis to AIDS by promoter alleles of IL10. Proc Natl Acad Sci U S A 97: 14467-14472.

95. Westendorp RG, Langermans JA, Huizinga TW, Elouali AH, Verweij CL, et al. (1997) Genetic influence on cytokine production and fatal meningococcal disease. Lancet 349: 170-173.

96. Cheong JY, Cho SW, Hwang IL, Yoon SK, Lee JH, et al. (2006) Association between chronic hepatitis $B$ virus infection and interleukin-10, tumor necrosis factor-alpha gene promoter polymorphisms. J Gastroenterol Hepatol 21: 11631169.

97. Lazarus M, Hajeer AH, Turner D, Sinnott P, Worthington J, et al. (1997) Genetic variation in the interleukin 10 gene promoter and systemic lupus erythematosus. J Rheumatol 24: 2314-2317.

98. Naicker DD, Wang B, Losina E, Zupkosky J, Bryan S, et al. (2012) Association of IL-10-promoter genetic variants with the rate of CD4 T-cell loss, IL-10 plasma levels, and breadth of cytotoxic T-cell lymphocyte response during chronic HIV1 infection. Clin Infect Dis 54: 294-302.
99. Naicker DD, Werner L, Kormuth E, Passmore JA, Mlisana K, et al. (2009) Interleukin-10 promoter polymorphisms influence HIV-1 susceptibility and primary HIV-1 pathogenesis. J Infect Dis 200: 448-452.

100. Chatterjee A, Rathore A, Sivarama P, Yamamoto N, Dhole TN (2009) Genetic association of IL-10 gene promoter polymorphism and HIV-1 infection in North Indians. J Clin Immunol 29: 71-77.

101. Kaliński P, Hilkens CM, Snijders A, Snijdewint FG, Kapsenberg ML (1997) IL-12-deficient dendritic cells, generated in the presence of prostaglandin E2, promotes type 2 cytokine production in maturing human naive $T$ helper cells. J Immunol 159: 28-35.

102. Hsieh CS, Macatonia SE, Tripp CS, Wolf SF, O'Garra A, et al. (1993) Development of TH1 CD4+ T cells through IL-12 produced by Listeria-induced macrophages. Science 260: 547-549.

103. Adoro S, Cubillos-Ruiz JR, Chen X, Deruaz M, Vrbanac VD, et al. (2015) IL21 induces antiviral microRNA-29 in CD4 T cells to limit HIV-1 infection. Nat Commun 6: 7562

104. Corrigan-Curay J, O'Reilly M, Kohn DB, Cannon PM, Bao G, et al. (2015) Genome editing technologies: Defining a path to clinic. Mol Ther 23: 796-806. 